\title{
Junk ingestion and nestling mortality in a reintroduced population of California Condors Gymnogyps californianus
}

\author{
ALLAN MEE, BRUCE A. RIDEOUT, JANET A. HAMBER, J. NICK TODD, \\ GREG AUSTIN, MIKE CLARK and MICHAEL P. WALLACE
}

\begin{abstract}
Summary
Ingestion of foreign anthropogenic material, here called junk, has been documented in many avian taxa but has become especially problematic in some Old World Gyps vulture populations within the last 30 years. Here, we document the effects of ingested junk on a reintroduced population of the Critically Endangered California Condor Gymnogyps californianus in southern California, U.S.A. Of 13 breeding attempts to date (2001-2005), only one has resulted in successful fledging. Of nests where either the nest substrate was sifted $(n=10)$ or nestlings ( $n$ $=8$ ) were examined, all but one held junk. Nine nestlings hatched in the wild between 2002 and 2005; of these six died at or near nests and two were removed from the wild for health reasons. Four dead nestlings and two removed from the wild held substantial quantities of junk. In two cases, junk ingestion was determined to be the cause of death. Five of six dead nestlings had elevated hepatic copper levels (150-531 ppm dry weight) although the significance of this, if any, remains undetermined. In comparison with historic condor nests $(n=69)$, junk was more prevalent and of greater size and quantity in reintroduced condor nests. To date, junk ingestion has been the primary cause of nest failure in the reintroduced condor population and threatens the reestablishment of a viable breeding population in southern California.
\end{abstract}

\section{Introduction}

In this year's nest was a practically perfect clam shell about an inch in diameter. This was lying on top of the leaf mould and dirt composing the floor, and could hardly have come there by natural means. There was also a piece of celluloid about eight inches long and two inches wide lying near the mouth of the cave. It is almost positive that these two objects were carried to the nest by the birds themselves. The celluloid was quite fresh and pliable, so could only have been there a short time. There were no traces of footprints either on the trail or up the only cliff face by which the nest can be reached, so no person could have been there. There was also a pellet of horsehair and manure of the nest floor, so possibly indigestible food is regurgitated after the manner of owls and some hawks. (A. J. Van Rossem unpubl. field notes)

The occurrence of foreign anthropogenic material, hereafter called junk, in the nests of the New World condors and the taxonomically unrelated Old World vultures has been documented at least since the noted ornithologist A. J. van Rossem made the above observation at a California Condor Gymnogyps californianus nest in Ventura County, California, U.S.A., in 1922. Although the provenance of the material is unknown in this case, the observation is noteworthy for three reasons: (i) it is the first observation that we are aware of suggesting condors bring junk 
to nests; (ii) it introduces a potential extraneous source of calcium (a clam shell); and (iii) it documents what appears to be pellet formation and casting by condors. However, it would be another 59 years before junk was again described from a condor nest (Snyder et al. 1986, Collins et al. 2000) despite intensive studies between 1939-1941 and 1945 (Koford 1953) and from 1966 to 1968 (F. Sibley, material deposited at the Santa Barbara Museum of Natural History).

In recent years, the occurrence of junk at nests of Old World Gyps vultures has become more widely documented although little exists in the published literature for many species (but see Mundy and Ledger 1976, Richardson et al. 1986, Ferro 2000, Benson et al. 2004). Junk ingestion has been widely documented in seabirds, particularly among procellariforms (e.g. Kenyon and Kridler 1969, Furness 1985, Huin and Croxall 1996), where it may lead to adult and nestling mortality (Pettit et al. 1981, Pierce et al. 2004). In some vulture populations, junk ingestion at nests has also been implicated in nestling mortality and poor nest success (Ferro 2000). Severe wing-deformities in Cape Vulture Gyps coprotheres nestlings (5-18\%) in the 1970s, and the prevalence of junk (30\% of items in nests and regurgitations by nestlings) possibly ingested in mistake for bone, suggested that calcium deficiency, apparently associated with the extirpation of large bone-crushing carnivores, was the primary cause of bone disorders (Mundy and Ledger 1976, Richardson et al. 1986). With the provision of bone fragments at feeding stations, the incidence of bone deformities among nestlings declined from $17 \%$ to $2.5 \%$ (Richardson et al. 1986). However, the importance of large mammals in determining accessibility to bones has been questioned (see Benson et al. 2004). Further, both bone and junk items may be sought as alternative food sources rather than as sources of calcium when meat is scarce (Benson et al. 2004).

With the recent initiation of breeding by reintroduced California Condors in southern California and northern Arizona, we had the opportunity to carry out intensive studies to determine nest success and identify potential limiting factors for the re-establishment of viable breeding populations in the wild. Previous intensive studies of the recent historic population of the 1980 os found no apparent problems in either breeding effort or nest success (Snyder and Hamber 1985, Snyder and Snyder 2000). Instead, the major limiting factor and the apparent cause of the catastrophic decline to near extinction of the condor population was high adult mortality primarily due to lead poisoning resulting from the ingestion of lead bullet fragments in the remains of hunter-killed animals (Janssen et al. 1986, Wiemeyer et al. 1988, Snyder and Snyder 2000). However, the intensive research at nests in the 1980 os (Snyder and Hamber 1985, Snyder and Snyder 2000) has provided an excellent baseline against which recent breeding efforts can be compared.

The California Condor is one of the most endangered birds in the world, with a current population, as of I January 2006, of 275 birds including 128 free-flying and 147 captive individuals (J. Grantham in litt. 2006). Reintroduction to the wild began in southern California (1992), northern Arizona (1996), central California (1997) and, most recently, Baja California, Mexico (2002). The first breeding attempts occurred in 2001 at the two former sites, with the first successful fledging in the wild in 2003 in northern Arizona. Here, we document the extent of junk at nests in a reintroduced population of condors in southern California and its effects on nest success.

\section{Study area and methods}

We studied condors nesting in the Los Padres National Forest, southern California, U.S.A. All condor breeding occurred in the Transverse Ranges $\left(34^{\circ} 46^{\prime} \mathrm{N}, 118^{\circ} 83^{\prime} \mathrm{W}\right)$ where nesting habitat was most often characterized by steep-sided canyons dominated by chaparral vegetation communities similar to those described for the historic condor population (Koford 1953, Snyder et al. 1986, Snyder and Snyder 2000). All condors are assigned individual studbook (SB) numbers for identification and population management purposes (Mace 2005). Free-flying condors were fitted with patagial tags with a unique number (last two digits of the SB number) and colour combination for individual identification. In addition, all condors were fitted with at 
least one conventional VHF radio-transmitter attached to the patagium and mounted on the wing (Wallace et al. 1994) or mounted on the tail attached to a central retrix. Some breeders were also fitted with patagial-mounted solar-powered satellite transmitters (PTTs). One female released in central California and now breeding in southern California was fitted with a GPS satellite transmitter.

To assess breeding behaviour and nest success we monitored breeding pairs throughout the year until nesting attempts either failed or succeeded in fledging a nestling. Parental care in condors is one of the most extreme of any bird species, including some 53-60 days of incubation and up to 6 months or more of brood care prior to fledging (Snyder and Schmitt 2002). Parental care also extends for several months post-fledging so that pairs successfully rearing a nestling in one year may skip breeding the next because of the demands of care (Snyder and Hamber 1985). During 2002-2005, we documented breeding attempts by condor pairs at 10 different nest-sites. One site used in 2001 was reused in 2004 by the same male paired with a new female. This nest was visited twice by A. M.: first to determine the cause of pre-hatching nest failure in 2001, and second to determine egg fertility in 2004. All but one nest, the last nest to fail in 2005, was visited at least once by A. M. and G. A. during or after the breeding attempt.

Nest-floor substrates were sifted at the end of breeding attempts or opportunistically during nest visits, using a fine-mesh window screen capable of collecting material greater than $1 \mathrm{~mm}^{2}$ as used by Collins et al. (2000). The primary purpose of sifting nest-cave substrates was to document and remove any junk items, condor eggshell fragments and faunal material for later identification. Condors do not carry items in the feet or bill, and all junk items found at nests were presumed to have been regurgitated by adults or nestlings. Observations and evidence from nests ruled out the possibility that Common Ravens Corvus corax might have brought junk to nests: (i) in over 5,00o hours of observations, ravens were observed landing at condor nests on only two occasions, and (ii) several junk items contained or had the hair of domestic cattle Bos taurus attached, indicating that these items had been ingested and regurgitated by condors. All junk was identified where possible and sorted by type (e.g. glass, plastic, metal). Junk was weighed using $50 \mathrm{~g}$, $100 \mathrm{~g}$ and $300 \mathrm{~g}$ pesolas and individual items measured (maximum length and width) to the nearest $0.1 \mathrm{~mm}$ using dial calipers. All materials recovered from nestcaves were deposited at the Santa Barbara Museum of Natural History (SBMNH). In addition, A. M., J. H. and N. T. examined and measured junk items recovered from historical condor nests $(n=69)$ during previous studies (Collins et al. 2000) for comparison with contemporary junk. Seventeen of these historical nests were visited twice but are included here as independent nest samples as they were carried out in different years following a new breeding attempt.

Dead nestlings were retrieved from nests or the immediate nest area and immediately transported to San Diego Zoo (SDZ) for post-mortem evaluation, which included whole-body dorsoventral and lateral X-rays followed by a complete necropsy. Tissues were fixed in 10\% neutral buffered formalin, processed routinely, embedded in paraffin, sectioned at $5 \mu \mathrm{m}$, and stained with haematoxylin and eosin. Liver samples from each case were frozen at $-20{ }^{\circ} \mathrm{C}$ for heavy-metal analysis (Toxicology Laboratory, California Animal Health and Food Safety Laboratory, Davis, California). Several different pathologists initially evaluated individual cases, but all were subsequently reviewed by one pathologist (B. R.). Three live nestlings with chronic health problems were rescued and removed to Los Angeles Zoo (LAZ) for emergency treatment and surgery. One severely debilitated nestling was subsequently euthanized. All nestlings were assessed for feather development, particularly the primaries, secondaries and retrices, on recovery from nests (by A. M.) or at necropsy (by B. R.). Nestlings were weighed and skeletal measurements taken: maximum wing chord, tarsus (knee to nail on middle toe, knee to foot pad), and head and bill length (nares to bill tip).

We used the SPSS 11.0 statistical package (SPSS, Chicago, Illinois) for data analysis. All tests were two-tailed and results were considered significant if $P<0.05$. Yates correction was applied to tests where there was one degree of freedom. 


\section{Results}

\section{Effects and prevalence of junk}

Of 13 breeding attempts in the wild in southern California to date (2001-2005), only one resulted in successful fledging. Nine nestlings hatched in the wild since 2002, six of which have died and two of which were removed from nests to captive breeding facilities for emergency care. Necropsy of the six dead nestlings revealed that in two cases death resulted directly from ingesting junk (Table 1). Three nestlings were severely decomposed, which significantly hindered histopathological evaluation. Despite the significant decomposition, the cause of death in one nestling (SB \#285) was confirmed to be acute zinc toxicosis (hepatic zinc 1,500 ppm dry weight) as a result of metallic foreign body ingestion (Figure 1 ). A second severely decomposed nestling (SB \#288) had significantly retarded growth, based on comparisons of feather development with captive hatched birds of the same age, and histological evidence of visceral gout. The cause of death in the third decomposed nestling (SB \#333) remains undetermined, but the most significant post-mortem finding was the large number of foreign bodies in the crop and gizzard (Figure 2). A fourth nestling (SB \#308) was euthanized due to chronic respiratory aspergillosis (fungal infection), which was diagnosed following surgery to remove foreign material from the stomach and gizzard. This bird also had significantly retarded feather development and growth.

The most recent nestling death ( $\mathrm{SB} \# 386$ ) was due to a West Nile virus infection, the first documented case in a California Condor (B. Rideout unpubl. data). Although the cause of death in this chick was unrelated to ingested junk found at necropsy, there was evidence of retarded growth, possibly related to junk ingestion. Cause of death in a sixth nestling (SB \#271) was undetermined, but this chick also had retarded growth. In addition, the hepatic copper level of this nestling was elevated compared with that documented in most avian species (e.g. 531 ppm dry weight vs approximately $61 \mathrm{ppm}$ dry weight for Turkey Vultures Cathartes aura; Risebrough et al. 2001). Interestingly, four other nestlings (SB \#288, \#308, \#333 and \#386) also had apparent elevations of hepatic copper (290 ppm, $212 \mathrm{ppm}, 341 \mathrm{ppm}$ and 150 ppm dry weight, respectively). Bone quality in all six nestlings was within normal limits based on gross and radiographic examination. Bone quality was also assessed histologically in five chicks (SB $\# 285, \# 288, \# 308, \# 333$ and \#386) and was within normal limits.

All but one nestling, SB \#271 in 2002, held some junk although another nestling, also in 2002, held only very small quantities of junk in its gizzard (Table 2). In all, six of the eight nestlings examined held substantial quantities of junk including glass shards, metal bottle-tops, washers, ammunition casings, electrical wiring and fittings, plastic PVC piping, pieces of rubber and even a $30 \mathrm{~cm}$ long piece of cloth (Figure 2). One nestling (SB \#328), which survived a fall

Table 1 . Causes of post-hatching nest failure of California Condors in California (2002-2005).

\begin{tabular}{|c|c|c|c|c|}
\hline \multirow[t]{2}{*}{ Primary cause } & \multicolumn{2}{|l|}{ Effect } & \multirow[t]{2}{*}{$\%$} & \multirow[t]{2}{*}{ Other data (no. of nestlings affected) } \\
\hline & Dead & Removed & & \\
\hline Junk & $2^{a}$ & 1 & $37 \cdot 5$ & $\begin{array}{l}\text { Zinc toxicosis ( } 1 \text { ), retarded growth (2), } \\
\text { elevated copper ( } 2 \text { ) }\end{array}$ \\
\hline Dehydration $^{b}$ & 1 & & 12.5 & Visceral gout, junk, elevated copper \\
\hline Fall from nest & & 1 & 12.5 & Broken wing, junk \\
\hline Undetermined & 2 & & 25.0 & Junk (1), elevated copper (2) \\
\hline West Nile virus & 1 & & 12.5 & Aspergillosis, junk, retarded growth \\
\hline
\end{tabular}

${ }^{a}$ One chick (SB \#308) removed from the nest on 11 September 2003 was euthanized at LAZ on 24 September 2003.

${ }^{b}$ Chick (SB \#288) went at least 6-8 days without food immediately before death during a period of hot weather. 


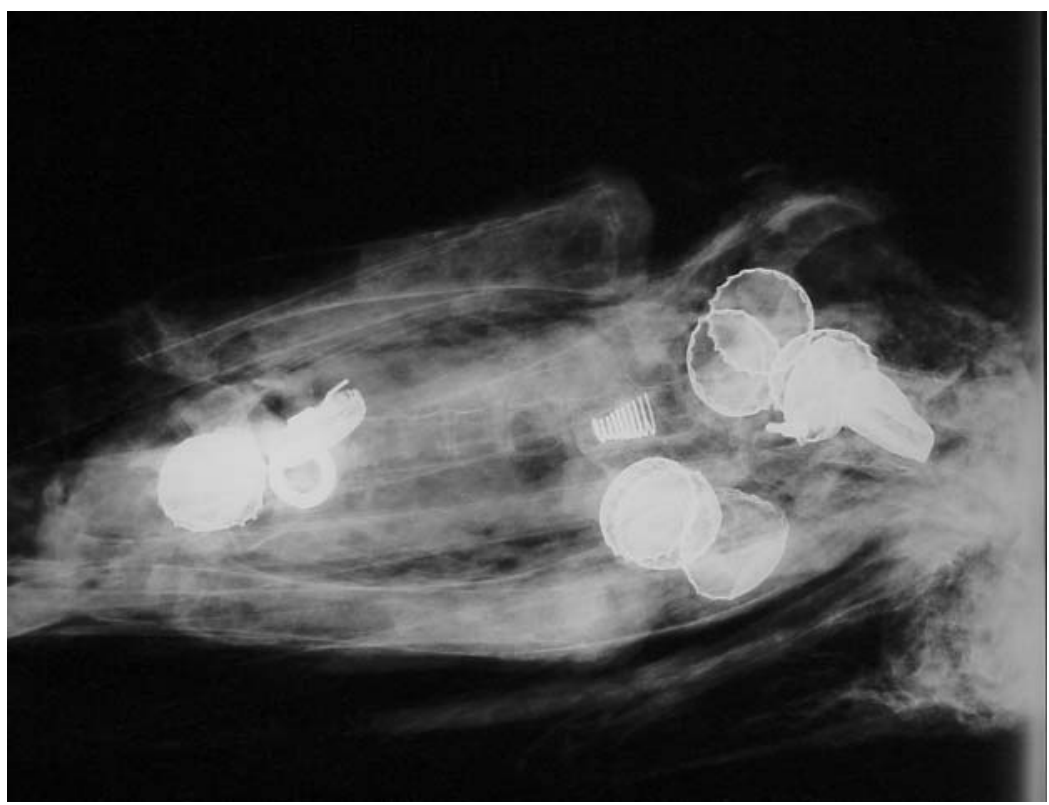

Figure 1 . Metallic foreign bodies ingested by nestling SB \#285.

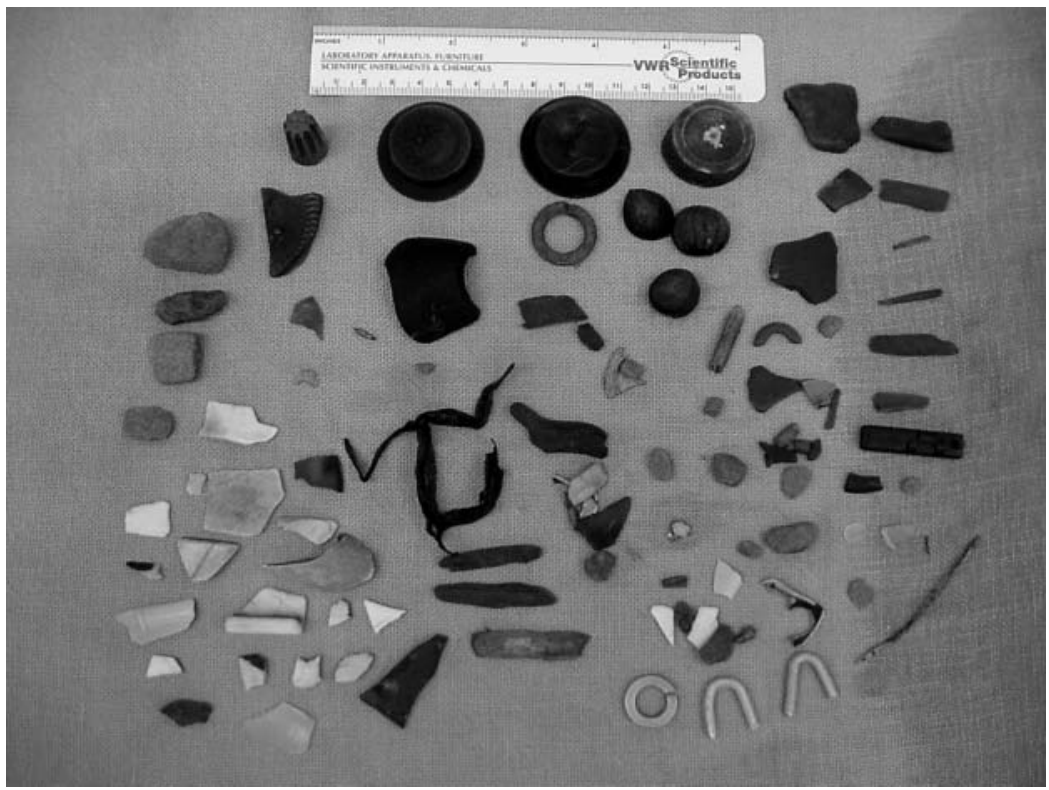

Figure 2. Foreign bodies in the crop and gizzard of nestling SB \#333.

from its nest at 117-121 days, had $222 \mathrm{~g}$ of foreign material (junk and naturally occurring material such as small stones and acorn shells; see Table 2) removed by surgery but was otherwise apparently healthy. A second surviving but debilitated nestling (SB \#370) removed from the nest at 118 days held $200 \mathrm{~g}$ of junk (Table 2). Of 650 junk items recovered from nests 
Table 2. Junk items recovered from California Condor nests and nestlings in Southern California (20012005).

\begin{tabular}{|c|c|c|c|c|c|c|c|c|c|c|c|}
\hline \multirow[t]{2}{*}{ Pair } & \multicolumn{4}{|c|}{ No. of nest items } & \multirow{2}{*}{$\begin{array}{l}\text { Weight } \\
(\mathrm{g})\end{array}$} & \multirow{2}{*}{$\begin{array}{l}\text { Chick } \\
\text { no. } \\
(\mathrm{SB})^{a}\end{array}$} & \multicolumn{4}{|c|}{ No. of items } & \multirow{2}{*}{$\begin{array}{l}\text { Weight } \\
(\mathrm{g})^{b}\end{array}$} \\
\hline & Metal & Glass & Plastic & Other & & & Metal & Glass & Plastic & Other & \\
\hline 2001 & & & & & & & & & & & \\
\hline $\mathrm{SC}_{2}$ & 1 & $\mathrm{O}$ & $\mathrm{O}$ & $\mathrm{o}$ & 24.0 & - & & & & & \\
\hline 2002 & & & & & & & & & & & \\
\hline $\mathrm{SC}_{1}$ & 1 & $\mathrm{o}$ & 7 & 6 & 9.0 & 271 & $\mathrm{O}$ & o & $\mathrm{O}$ & o & 0.0 \\
\hline $\mathrm{SC}_{3}$ & 15 & 9 & 14 & 4 & 56.5 & 285 & 15 & 27 & 34 & 7 & $79 \cdot 5$ \\
\hline $\begin{array}{l}\mathrm{SC}_{2} \\
2 \mathrm{OO} 3\end{array}$ & o & o & o & o & $\mathrm{o}$ & 288 & $\mathrm{o}$ & 1 & 11 & 4 & $7 \cdot 3$ \\
\hline $\begin{array}{l}\mathrm{SC}_{4} \\
2004\end{array}$ & o & 2 & 9 & 2 & 18.8 & 308 & 10 & 5 & 12 & 4 & $25.0^{c}$ \\
\hline $\mathrm{SC}_{5}{ }^{d}$ & O & $\mathrm{o}$ & o & o & - & 326 & - & - & - & - & - \\
\hline $\mathrm{SC}^{d}$ & o & $\mathrm{o}$ & o & o & - & 328 & 44 & 45 & 14 & 6 & $193 \cdot 5^{e}$ \\
\hline $\begin{array}{l}\mathrm{SC}_{4} \\
2005\end{array}$ & o & o & 1 & o & 0.1 & 333 & 7 & 6 & 32 & 12 & $60.0^{f}$ \\
\hline SC6 & 11 & 55 & o & 1 & 172.5 & 370 & 30 & 54 & 82 & 2 & $200.5^{g}$ \\
\hline $\mathrm{SC}_{7}^{d}$ & o & 0 & 1 & 4 & 3.0 & - & & & & & \\
\hline $\mathrm{SC}_{4}$ & - & - & - & - & - & 386 & 14 & 19 & 9 & 1 & $73 \cdot 4^{h}$ \\
\hline
\end{tabular}

${ }^{a}$ California Condor Studbook number (Mace 2005).

${ }^{b}$ Weight of items recovered from nestlings by necropsy $(n=5)$, or surgery $(n=3)$ to remove foreign material.

${ }^{c}$ Total weight including natural material (one piece woody vegetation) $=30 \mathrm{~g}$.

${ }^{d}$ Nests visited during the egg stage only; only a visual check of SC 5 , SC6 (2004); SC7 egg predated.

${ }^{e}$ Total weight including natural material (25 stones, three acorns, six woody vegetation) $=222.5 \mathrm{~g}$.

${ }^{f}$ Total weight including natural material (20 stones, five acorns, 16 woody vegetation, $67 \mathrm{~g}$ of hair) $=166.3 \mathrm{~g}$.

${ }^{8}$ Total weight including natural material (three stones, one bone, five pieces of woody vegetation) $=204.5 \mathrm{~g}$.

${ }^{h}$ Total weight including natural material (10 stones, three acorns, one piece woody vegetation, large amount of hair) $=95 \cdot 3 \mathrm{~g}$.

and condor nestlings, $226(34.8 \%)$ were plastic, 223 (34.3\%) were glass, 148 (22.8\%) were metallic and $53(8.1 \%)$ were other materials. Most junk items were brown in colour $(36.7 \%)$, followed in prevalence by transparent, mostly glass items (19.5\%), white (14.7\%), silver, primarily metallic items $(13.5 \%)$, blue $(5.1 \%)$, black $(4.2 \%)$, red $(3.9 \%)$, opaque $(1.9 \%)$ and green items (1.1\%).

\section{Comparison with historical nests}

We also compared the prevalence of junk in historical and reintroduced condor nests in California. Almost no faunal items (i.e. bone) were found at reintroduced condor nests. Of 10 sites visited, two bone fragments at one nest, identified as that of a calf, were the only items found that were likely to have come from a provisioned food source. Junk was significantly more prevalent and numerous in reintroduced condor nests $\left(\chi_{1}^{2}=15.75, P<0.001\right.$; Table 3$)$. Further, the number of junk items at historical nests was skewed by the occurrence of 53 items at one nest in 1984, most of which appeared to be derived from a few items (e.g. nine, 16 and 19 small fragments from an aluminium can, a piece of brown and opaque plastic, respectively). The remaining seven historical nests held only seven or fewer junk items. Junk from reintroduced condor nests was also significantly larger (Mann-Whitney test, $Z=2.58, P=0.01, n=8,7$ ) and had a greater overall mass $(Z=2.15, P=0.03, n=8,7)$ than that from historical nests (Table 3 ). Only in three nests could the size of junk remaining at nests and that recovered from 
Table 3. Prevalence, quantity and characteristics of junk at historical and reintroduced condor nests in California.

\begin{tabular}{|c|c|c|c|c|c|c|c|c|}
\hline \multirow[t]{2}{*}{ Population } & \multirow[t]{2}{*}{$n$} & \multirow{2}{*}{$\begin{array}{l}\text { Nests } \\
\text { with junk } \\
(\%)^{a}\end{array}$} & \multicolumn{2}{|c|}{$\begin{array}{l}\text { Items per nest } \\
\left(\text { all nests) }{ }^{b}\right.\end{array}$} & \multicolumn{2}{|c|}{$\begin{array}{l}\text { Junk max. length } \\
(\mathrm{mm})^{c}\end{array}$} & \multicolumn{2}{|c|}{ Junk weight $(\mathrm{g})^{c}$} \\
\hline & & & Median & Range & $\begin{array}{l}\text { Mean } \\
( \pm S D)\end{array}$ & Range & $\begin{array}{l}\text { Mean } \\
( \pm S D)\end{array}$ & Range \\
\hline Historic & 69 & $8(12)$ & o & $\mathrm{o}-53$ & $\begin{array}{l}18.0^{d} \\
( \pm 16.4)\end{array}$ & $2.9-34.2$ & $\begin{array}{l}8.6^{e} \\
( \pm 18.6)\end{array}$ & $0.1-57 \cdot 5$ \\
\hline Reintroduced & 10 & $7(70)$ & 9 & $0-67$ & $\begin{array}{l}27.4 \\
( \pm 9.2)\end{array}$ & $7 \cdot 8-54 \cdot 3$ & $\begin{array}{l}36.4 \\
( \pm 57 \cdot 9)\end{array}$ & $0.1-172.5$ \\
\hline
\end{tabular}

${ }^{a}$ Junk recovered from nests only (nestlings excluded) for direct comparison with historical condor nests.

${ }^{b}$ Median derived from number of items in all nests with or without junk.

${ }^{c}$ Size of individual junk items; means derived from nests holding junk only.

${ }^{d}$ Historic mean length $=13.6 \mathrm{~mm}( \pm$ SD 6.9) if junk at one nest (two flashbulbs) probably left by humans is excluded.

${ }^{e}$ Historic mean weight $=2.2 \mathrm{~g}( \pm 2.9)$, range $=0.1-7.0$ if junk at one nest (two flashbulbs) probably left by humans is excluded.

nestlings in the same nest be compared. The mean length of items recovered from nestlings was somewhat smaller at all three sites than junk from nests (overall mean $=22.6 \mathrm{~mm} \pm \mathrm{SD} 0.57 \mathrm{vs}$ $27.3 \mathrm{~mm} \pm \mathrm{SD}$ 1.36, $n=3$ ). The largest solid junk items recovered were $54.3 \mathrm{~mm}$ (nests) and $53.3 \mathrm{~mm}$ (nestlings) in length. However, a bone found at one nest in 2003 was substantially larger $(94.8 \mathrm{~mm})$.

All but two historical nests holding junk were from the years just prior to capture of the last wild birds, when eggs and nestlings were being removed from the wild to help form a captive flock for future breeding (1982-1986). One exception was the 1922 nest visited by van Rossem. The second was a nest studied by Koford (plate 19 in Koford 1953), subsequently visited by Sibley in 1966 (F. Sibley unpubl. data) and Snyder and Roberts in 1982 (N. Snyder unpubl. data). Sibley discovered "four old-style flashbulbs found around the cave entrance and buried there". Two were recovered at the site in 1982 (see p. 28 in Snyder and Snyder 2000) and probably dated from nest photography at the site in the 1940s (Bleitz 1946). Both celluloid, developed as a lightweight replacement for heavy glass photographic plates, and flashbulbs at these nests suggest that the material was left either at or near these nest-sites following nest photography. However, given the slight possibility that condors may have ingested and moved them to their nests, we included these nests in the analysis (Table 3 ).

\section{Discussion}

\section{Junk ingestion and nestling mortality}

Nest success of reintroduced California Condors has been extremely low to date in southern California. Our results document the detrimental effects of junk ingestion on nestling survival and the high prevalence of junk in nests. Despite the presence of junk in some historical nests there was no apparent negative effect on nest success (Snyder and Snyder 1989, 2000). Of nine chicks produced during the 1980s (1980-1984), all but one (died during handling) fledged successfully $(n=4)$ or were taken into captivity $(n=4)$ late in the nestling phase to help form a future captive breeding effort. Of the eight historical nests holding junk, three produced chicks (all others had been used in previous years where the outcome was unknown). One of these chicks fledged successfully while the other two were taken into captivity. Thus, current levels of junk ingestion clearly surpass that found in the historical breeding population. However, we urge caution in comparing populations as some nestlings in the historical population were 
removed from the wild prior to fledging (1982-1984) or were never physically examined to check for the presence of junk. While Koford (1953) apparently did not find junk in the condor nests he visited, he mentions the death of three condors in captivity in the early twentieth century attributed to swallowing foreign material (a rubber band, a stick and rubber from a hose).

In this study, junk ingestion was determined to be the cause of death in two nestlings. However, the preponderance of evidence suggests that junk ingestion was the primary contributing factor in the deaths of four nestlings. In one nestling, junk ingestion resulted in zinc toxicity. Four nestlings showed retarded feather development; in three of these nestlings this possibly resulting from distention of the crop and gizzard by indigestible material and, thus, reduced ability to take in adequate amounts of food to meet the caloric demands of growth (see also Pierce et al. 2004). However, one nestling (SB \#288) showing retarded feather development had only small amounts of junk while another nestling (SB \#328) that fell from a nest and held a large quantity of junk had apparently normal development. Secondary respiratory aspergillosis followed in one nestling, ultimately resulting in euthanasia. Another nestling had no definitive histological diagnosis, but ingested junk was the most significant post-mortem finding. There was no gross, histological or radiological evidence of diminished bone quality in the affected nestlings. However, all these methods of assessing bone quality are relatively crude and could easily overlook subclinical reductions in bone quality.

Elevated hepatic copper was also recorded in five of the six dead nestlings, but the significance of this remains to be determined. However, California Condors appear to accumulate higher concentrations of copper in their livers (range 73-603 ppm dry weight for 12 dead condors examined between 1976 and 2000; see Wiemeyer et al. 1983, 1988, Risebrough et al. 2001) than Turkey Vultures (43-78 ppm dry weight, $n=9)$, even including Turkey Vultures experimentally dosed with copper (55-84 ppm dry weight, $n=10$; Risebrough et al. 2001). Hepatic copper levels vary dramatically within and between avian taxa: levels are 4-446 ppm in seabirds (see Eisler 1998) but apparently normal Mute Swans Cygnus olor, for example, can have levels above 800 ppm (Clausen and Wolstrup 1978).

\section{Condor behaviour and junk ingestion}

Although adult condors ingest junk, this material has only been implicated as a mortality factor among nestlings as no free-flying condor has been found with significant quantities of ingested junk at necropsy. This suggests that free-flying condors ingesting junk appear to have little problem regurgitating the material. So why could this be affecting only nestlings? A possible explanation is that nestlings may be physiologically less competent at regurgitating pellets or other indigestible material than adults. Also, to form pellets vultures sometimes appear to need to have access to fibrous material that binds to indigestible items. Such material is generally not available to cave-bound nestlings. Moreover, we rarely observed what appeared to be nestlings attempting to regurgitate pellets (A. M. unpubl. data). California Condors appear to cast pellets rather rarely compared with the smaller cathartid vultures (see Rea 1973, Paterson 1983, Iñigo Elías 1987), presumably reflecting the greater prevalence of muscle and other soft tissues, and the paucity of indigestible items such as hide or hair in the condor diet. However, condors are probably most likely to cast pellets at roosts and these sites have not been searched systematically. This may also partly be an artefact of the greater dependence of reintroduced condors on a single food-type (calf carcasses) at provisioned sites compared with the greater variety of small mammals in the diet of condors in the historic population (Koford 1953, Snyder et al. 1986). Thus, Koford (1953) frequently documented castings at or near nests.

So why do condors pick up junk? Junk ingestion appears to be reasonably common among other large vultures, where it has been associated with the need to provide calcium for nestling development: vultures mistaking junk for bone fragments (Mundy and Ledger 1976, Richardson et al. 1986). However, calcium demand is not the only plausible hypothesis (see Benson et al. 
2004). In southern California, provision of calcium in the form of bone fragments and small mammals as a more accessible source of bone at condor feeding sites, has had no noticeable effect on the quantity of junk delivered to nests and nestling survival. This cannot be regarded as a rigorous test of the calcium demand hypothesis, though, as the provision of both bone and alternative food sources (rats and rabbits) have been inconsistent and the quantity of small mammals has probably been too small to affect the target birds, with Common Ravens and Golden Eagles Aquila chrysaetos often reaching carcasses first and breeders having to compete with 20 or more other condors. Although a number of nestlings affected by junk have shown retarded feather development possibly explained by calcium deficiency, this has not been the case with all nestlings. Poor feather growth could equally be explained by the direct effects of crop impaction, nutritional problems or both. Moreover, gross histopathological and radiographical evidence to date has not indicated any apparent problems with bone density. Apart from one nest in 2002, white, bone-like junk only comprised a small sample of the junk items recovered from nests and nestlings. White items and untinted glass combined made up over $90 \%$ and $82.5 \%$ of junk found at the base of nest-cliffs and in the crops of Cape Vultures respectively (Benson et al. 2004) but only $34 \%$ combined for condors in this study.

\section{Junk ingestion: conservation solutions}

Condors' propensity to ingest junk may also be an indication of a growing and deeper human footprint on the environment in southern California. The recent successful fledging of condor nestlings in northern Arizona may have resulted, at least partly, from the relatively less impacted environment of the greater Grand Canyon area and the development of more natural foraging patterns, albeit with the serious downside of increased rates of lead toxicity. In this release region a significant proportion of the condor diet is made up of food from nonprovisioned sources, principally mule deer Odocoileus hemianus, elk Cervus elaphus and coyotes Canis latrans, as well as range cattle and mules (S. Osborn pers. comm.). Further, most nests have been distant from feeding sites (up to $80 \mathrm{~km}$ ) with condor parents having to travel extensively to find both provisioned and non-provisioned food. In contrast, all nests to date in southern California have been within $12 \mathrm{~km}$ of provisioned feeding sites and some have been less than $2.5 \mathrm{~km}$ distant. Moreover, almost all food brought to nests by the most intensively monitored nesting pairs has come from provisioned sites (A. M. unpubl. data).

In contrast to previous studies of California Condors in the historic population (Koford 1953, Collins et al. 2000) we found almost no faunal items at nests, and bone fragments were almost completely absent. Apart from being a source of calcium, bone is an excellent source of energy and protein (Houston and Copsey 1994) and may be an important alternative food resource when meat is limited (Benson et al. 2004). Further, wild Cape Vulture nestlings consumed nest material, resulting in impacted crops, apparently in response to hunger when they were fooddeprived (Dobbs and Benson 1984). Studies of California Condor nests in the reintroduced southern California population have revealed that although feeding rates were similar overall to those in historic nests, provisioning at individual nests was much more variable, with nestlings suffering more prolonged periods of food deprivation at reintroduced condor nests (Mee et al. 2007). More importantly perhaps, reintroduced condors in southern California are heavily dependent on food provided at a single source "restaurant" in an effort to maintain condors on food free of lead contamination and thus reduce mortalities. While such management has apparently been effective in reducing the risk of lead contamination, the impact on the development of natural foraging patterns have been profound.

The deleterious effects of junk ingestion on condor nest success now seriously threaten the long-term re-establishment of a viable, self-sustaining breeding population in southern California. Efforts have been made by the US Forest Service to clean up sites frequented by condors. However, the scale and diversity of sites likely to hold quantities of junk are huge. Most frequented sites are at the southern end of the population's range in southern California, close to 
major centres of human population. We propose, as a matter of urgency, the provisioning of condors at multiple feeding sites away from problem areas, and increasing the nutritional diversity and value of provisioned food. However, an increase in the foraging ranges of condors is likely to result in increased exposure to lead (see Meretsky et al. 200o). Removing the threat of lead poisoning from the condor range would allow greater flexibility for the management of condor populations. Further, we plan to expand the provision of bone fragments to all nests during visits to nests to vaccinate nestlings for West Nile virus and carry out health checks. We also recommend that captive trials be undertaken to determine nutritional requirements and timing of bone mineralization in nestling condors as well as the potential for aversive conditioning of condors ingesting junk.

\section{Acknowledgments}

We thank the US Fish \& Wildlife Service (USFWS) for permission to study condors at breeding sites in southern California and the US Forest Service for permission to access sites. Many people have directly assisted or cooperated in this work. USFWS condor crews including Colleen Beestman, Joseph Brandt, Richard Posey, Dan Tappe and Lance Woolaver assisted with entry to one or more nests. Drs Cynthia Stringfield, Leah Greer (LAZ) and Jeff Zuba (San Diego Wild Animal Park) provided veterinary expertise in the field, often under extremely difficult conditions. Aspen Helicopters, Oxnard, flew several recovered birds and occasionally recovering humans out of the backcountry. Dr Rebecca Papendick and April Gorow (SDZ) performed many necropsies, provided photographs and recovered junk from nestlings. Dr Steve Klause (LAZ) performed surgery to remove junk on two condor nestlings, both of which are recovering well and are scheduled for release in the future. Special thanks go to LAZ condor keepers Chandra David, Marti Jenkins and Debbie Sears. Paul Collins (SBNHM) provided access to historical condor nest remains. We thank David Houston and Linnea Hall for helpful comments on the manuscript and Mark Anderson for providing some relevant references. A. M. thanks the Zoological Society of San Diego and the Offield Foundation for their financial support.

\section{References}

Benson, P. C., Plug, I. and Dobbs, J. C. (2004) An analysis of bones and other materials collected by Cape Vultures at the Kransberg and Blouberg colonies, Limpopo Province, South Africa. Ostrich 75: 118-132.

Bleitz, D. (1946) Climbing for condors. Pacific Pathways 1(10): 37-41.

Clausen, B. and Wolstrup, C. (1978) Copper load in mute swans (Cygnus olor) found in Denmark. Nord. Vet. Med. 30: 260-266.

Collins, P. W., Snyder, N. F. R. and Emslie, S. D. (2000) Faunal remains in California Condor nest caves. Condor 102: 222-227.

Dobbs, J. C. and Benson, P. C. (1984) Behavioural and metabolic responses to food deprivation in the Cape Vulture. Pp. 211-214 in J. M. Mandelsohn and C. W. Sapsford, eds. Proceedings of the
Second Symposium on African Predatory Birds. Durban: Natal Bird Club.

Eisler, R. (1988) Copper hazards to fish, wildife, and invertebrates: a synoptic review. US Geological Survey, Biological Resources Division, Biological Science Report USGS/BRD/BSR - 1998-0002.

Ferro, M. (2000) Consumption of metal artefacts by Eurasian Griffons at Gamla Nature Reserve, Israel. Vulture News 43: 46-48.

Furness, R. W. (1985) Ingestion of plastic by seabirds at Gough Island, South Atlantic Ocean. Environ. Pollut. Ser. A 38: 261-272.

Houston, D. C. and Copsey, J. (1994) Bone digestion and intestinal morphology of the Bearded Vulture. J. Raptor Res. 28: 73-78.

Huin, N. and Croxall, J. P. (1996) Fishing gear, oil and marine debris associated with 
seabirds at Bird Island, South Georgia, during 1993/1994. Mar. Orn. 24: 19-22.

Iñigo Elías, E. E. (1987) Feeding habits and ingestion of synthetic products in a Black Vulture population from Chiapas, Mexico. Acta Zool. Mex. 22: 1-15.

Janssen, D. L., Oosterhuis, J. E., Allen, J. L., Anderson, M. P., Kelts, D. G. and Wiemeyer, S. N. (1986) Lead poisoning in free-ranging California Condors. J. Am. Vet. Med. Assoc. 189: 1115-1117.

Kenyon, K. W. and Kridler, E. (1969) Laysan albatross swallow indigestible matter. Auk 86: 339-343.

Koford, C. B. (1953) The California Condor. Natl. Audubon Res. Rep. No. 4: 1-154.

Mace, M. E. (2005) California Condor (Gymnogyps californianus) International Studbook Escondido, CA: Zoological Society of San Diego, San Diego Wild Animal Park.

Mee, A., Hamber, J. A. and Sinclair, J. (2007) Low nest success in a reintroduced population of California Condors. In A. Mee and L. Hall, eds. California Condors in the 21st century. Cambridge, MA and Washington, DC: American Ornithologist's Union and Nuttall Ornithological Club. (In press.)

Meretsky, V. J., Snyder, N. F. R., Beissinger, S. R., Clendenen, D. A. and Wiley, J. W. (2000) Demography of the California Condor: implications for reestablishment. Conserv. Biol. 14: 957-967.

Mundy, P. J. and Ledger, J. A. (1976) Griffon vultures, carnivores and bones. S. Afr. J. Sci. 72: 106-110.

Paterson, R. L. (1983) High incidence of plant material and small mammals in the autumn diet of Turkey Vulture. Wilson Bull. 96: 467-469.

Pettit, T. N., Grant, G. S. and Whittow, G. C. (1981) Ingestion of plastics by Laysan Albatross. Auk 98: 839-841.

Pierce, K. E., Harris, R. J., Larned, L. S. and Pokras, M. A. (2004) Obstruction and starvation associated with plastic ingestion in a Northern Gannet Morus bassanus and a Greater Shearwater Puffinus gravis. Mar. Orn. 32: 187-189.

Rea, A. M. (1973) Turkey Vultures casting pellets. Auk 90: 209-210.
Richardson, P. R. K., Mundy, P. J. and Plug, I. (1986) Bone crushing carnivores and their significance to osteodystrophy in griffon vulture nestlings. J. Zool. Lond. 210: 23-43.

Risebrough, R. W., Valencia, R., Clendenen, D., Mason, A. Z., Bloom, P. H., Wallace, M. P. and Mesta, R. (2001) Absence of demonstrable toxicity to Turkey Vultures, Cathartes aura, of copper and tungstentin-bismuth-composite pellets. Final Report to US Fish and Wildlife Service, California Condor Recovery Program, Ventura, CA, under Contract 14-48-ooo195822. Berkeley, CA: The Bodega Bay Institute.

Snyder, N. F. R. and Hamber, J. A. (1985) Replacement clutching and annual nesting of California Condors. Condor 87: $374-378$.

Snyder, N. F. R. and Schmitt, N. J. (2002) California Condor (Gymnogyps californianus). In A. Poole and F. Gill, eds. Birds of North America. No. 610. Philadelphia, PA: The Birds of North America, Inc.

Snyder, N. F. R. and Snyder, H. (1989) Biology and conservation of the California Condor. Curr. Ornithol. 6: 175-267.

Snyder, N. F. R. and Snyder, H. (2000) The California Condor, a saga of natural history and conservation. London, U.K: Academic Press.

Snyder, N. F. R., Ramey, R. R. and Sibley, F. C. (1986) Nest site biology of the California Condor. Condor 88: 228-24I.

Wallace, M. P., Fuller, M. and Wiley, J. (1994) Patagial transmitters for large vultures and condors. Pp. $381-387$ in B. U. Meyburg and R. D. Chancellor, eds. Raptor conservation today. London: World Working Group on Birds of Prey and Owls and Pica Press.

Wiemeyer, S. N., Krynitsky, A. J. and Wilbur, S. R. (1983) Environmental contaminants in tissues, foods, and feces of California condors. Pp. 427-439 in S. R. Wilbur and J. A. Jackson, eds. Vulture biology and management. Berkeley, CA: University of California Press.

Wiemeyer, S. N., Scott, J. M., Anderson, M. P., Bloom, P. H. and Stafford, C. J. 
(1988) Environmental contaminants in California Condors. J. Wildl. Manage. 52: 238-247.

Woods, C. P., Heinrich, W. R., Farry, S. C., Parish, C. N., Osborn, S. A. H. and Cade, T. J. (2007) Survival and reproduction of
California Condors released in Arizona. In A. Mee and L. Hall, eds. California Condors in the 21st century. Cambridge, MA, Washington, DC: American Ornithologists Union and Nuttall Ornithological Club. (In press.).

\section{ALLAN MEE*, MICHAEL P. WALLACE}

CRES, Zoological Society of San Diego, 15600 San Pasqual Valley Road, Escondido, CA 920277000, USA.

\section{BRUCE A. RIDEOUT}

Department of Pathology, San Diego Zoo, P. O. Box 120551, San Diego, CA 92112-0551, USA.

\section{JANET A. HAMBER}

Santa Barbara Museum of Natural History, 2559 Puesta del Sol, Santa Barbara, CA 93105, USA.

\section{J. NICK TODD}

Santa Cruz Predatory Bird Research Group, 100 Shaffer Road, U.C. Santa Cruz, Long Marine Laboratory, Santa Cruz, CA 95060, USA.

\section{GREG AUSTIN}

US Fish \& Wildlife Service, Hopper Mountain National Wildlife Refuge 2493 Portola Road, Suite A, Ventura CA 93005, USA.

\section{MIKE CLARK}

Los Angeles Zoo, 5333 Zoo Drive, Los Angeles, CA 90027, USA.

${ }^{*}$ Author for correspondence. Killarney National Park, Muckross, Killarney, Co. Kerry, Ireland; e-mail: allan.mee@ireland.com

Received 23 December 2005; revision accepted 10 May 2006 